\title{
A note on some positive linear operators associated with the Hermite polynomials
}

\section{GRAŻYNA KRECH}

\section{ABSTRACT.}

In this paper we give direct approximation theorems and the Voronovskaya type asymptotic formula for certain linear operators associated with the Hermite polynomials. These operators extend the well-known SzászMirakjan operators.

Acknowledgement. The author would like to thank the referees for a careful reading of the manuscript, suggestions and comments, which improved the presentation of the paper.

\section{REFERENCES}

[1] Andrews, L. C., Special Functions for Engineers and Applied Mathematicians, Mac Millan, New York, 1985

[2] Appell, P. and Kampé de Fériet, J., Fonctions Hypergéométriques et Hypersphériques; Polynômes d'Hermite, Gauthier-Villars, Paris 1926

[3] Babusci, D., Dattoli, G. and Quattromini, M., On integrals involving Hermite polynomials, Appl. Math. Lett., 25 (2012), 1157-1160

[4] Bărbosu, D., Generalized blending operators of Favard-Szasz type, Bul. Ştiinţ. Univ. Baia Mare Ser. B, 10 (1994), No. $1-2,45-51$

[5] Bărbosu, D., Some applications of Shisha-Mond theorem, Creat. Math. Infor., 23 (2014), No. 2, 141-146

[6] Bărbosu, D., Pop, O. T. and Miclăuş, D., On some extensions for the Szász-Mirakjan operators, An. Univ. Oradea Fasc. Mat., 18 (2011), No. 1, 179-187

[7] Bărbosu, D., Pop, O. T. and Miclăuş, D., The Kantorovich form of some extensions for Szász-Mirakjan operators, Rev. Anal. Numér. Théor. Approx., 39 (2010), No. 1, 8-20

[8] Bardaro, C. and Mantellini, I., Approximation properties in abstract modulaar spaces for a class of general sampling operators, Applicable Analysis, 85 (2006), No. 4, 383-413

[9] Bardaro, C. and Mantellini, I., A quantitative asymptotic formula for a general class of discrete operators, Comput. Math. Appl., 60 (2010), No. 10, 2859-2870

[10] Bardaro, C. and Mantellini, I., Asymptotic formulae for bivariate discrete operators: applications to generalized sampling series and Szász-Mirakjan operators, Panamer. Math. J., 20 (2010), No. 1, 1-21

[11] Bardaro, C. and Mantellini, I., A Voronovskaya type theorem for a general class of discrete operators, Rocky Mountain J. Math., 39 (2009), No. 5, 1411-1442

[12] Becker, M., Global approximation theorems for Szász-Mirakjan and Baskakov operators in polynomial weight spaces, Indiana Univ. Math. J., 27 (1978), No. 1, 127-142

[13] Becker, M., Kucharski, D. and Nessel, R. J., Global approximation theorems for the Szász-Mirakjan operators in exponential weight spaces, Linear Spaces and Approximation Proc. Conf. (Oberwolfach, 1977), Birkhäuser Verlag, Basel, Internat. Series of Num. Math., 40 (1978), 319-333

[14] Butzer, P. L. and Karsli, H., Voronovskaya-type theorems for derivatives of the Bernstein-Chlodovsky polynomials and Szász-Mirakjan operators, Comment. Math. 49 (2009), No. 1, 33-58

[15] Dattoli, G., Srivastava, H. M. and Zhukovsky, K., Ortogonality properties of the Hermite and related polynomials, J. Comput. Appl. Math., 182 (2005), 165-172

Received: 27.12.2014; In revised form: 18.11.2015; Accepted: 25.11.2015

2010 Mathematics Subject Classification. 41A25, 41A36.

Key words and phrases. Positive linear operators, approximation order, Voronovskaya type theorem, Hermite polynomials. 
[16] Dattoli, G., Generalized polynomials, operational identities and their applications, J. Comput. Appl. Math., 118 (2000), 111-123

[17] DeVore, R. A. and Lorentz, G. G., Constructive Approximation, Springer-Verlag, Berlin, 1993

[18] Ditzian, Z. and Totik, V., Moduli of Smoothness, Springer-Verlag, New York, 1987

[19] Duman, O. and Özarslan, M. A., Szász-Mirakjan type operators providing a better error estimation, Appl. Math. Lett., 20 (2007), 1184-1188

[20] Gonska, H., Piţul, P. and Raşa, I., General King type operators, Result. Math., 53 (2009), No. 3-4, 279-286

[21] Johnen, H. and Scherer, K., On equivalence of $K$ functional and moduli of continuity and some applications, Constructive Theory of Functions of Several Variables, Proc. Conf. (Oberwolfach, 1976), Lecture Notes in Mathematics, 571, Springer-Verlag, 119-140

[22] Lebedev, N. N., Special Functions and their Applications, Dover, New York, 1972

[23] Louisell, W. H., Quantum Statistical Properties of Radiation, Wiley, New York, 1990

[24] Mahmudov, N. I., $q$-Szász-Mirakjan operators which preserve $x^{2}$, J. Comput. Appl. Math., 235 (2011), 4621-4628

[25] Mortici, C., An extension of the Szász-Mirakjan operators, An. St. Univ. "Ovidius" Constanta, 17 (2009), No. 1, $137-144$

[26] Păltănea, R., Optimal estimates with moduli of continuity, Result. Math., 32 (1997), 318-331

[27] Pop, O. T., Bărbosu, D. and Miclăuş, D., The Voronovskaja type theorem for an extension of Szász-Mirakjan operators, Demonstratio Math., 45 (2012), No. 1, 107-115

[28] Pop, O. T., Miclăuş, D. and Bărbosu, D., The Voronovskaja type theorem for a general class of Szász-Mirakjan operators, Miskolc Math. Notes, 14 (2013), No. 1, 219-231

[29] Rempulska, L. and Graczyk, S., Approximation by modified Szász-Mirakjan operators, JIPAM, Journal Inequal. Pure Appl. Math., 10 (2009), No. 3, art. 61

[30] Rempulska, L. and Graczyk, S., On certain class of Szász-Mirakjan operators in exponential weight spaces, Int. J. Pure Appl. Math., 60 (2010), No. 3, 259-267

[31] Rempulska, L. and Walczak, Z., Modified Szász-Mirakyan operators, Mathematica Balkanica, 18 (2004), 53-63

[32] Shisha, O. and Mond, B., The degree of convergence of linear positive operators, Proc. Nat. Acad. Sci. U.S.A., 60 (1968), 1196-1200

[33] Szász, O., Generalizations of S. Bernstein's polynomials to the infinite interval, J. Res. Nat. Bur. Standars, Sect. B, 45 (1950), 239-245

[34] Toczek, G. and Wachnicki, E., On the rate of convergence and the Voronovskaya theorem for the Poisson integrals for Hermite and Laguerre expansions, J. Approx. Theory, 116 (2002), 113-125

[35] Totik, V., Uniform approximation by Szász-Mirakjan type operators, Acta Math. Hungar., 41 (1983), No. 3-4, 291-307

[36] Xie, L. and Xie, T., Approximation theorems for localized Szász-Mirakjan operators, J. Approx. Theory, 152 (2008), $125-134$

Pedagogical University of CRACOW

INSTITUTE OF MATHEMATICS

UL. PODCHORA̧ŻYCH 2, PL-30-084 KRAKÓW, POLAND

E-mail address: gkrech@up.krakow.pl 